\title{
MINIMIZING CORRUPTION BY OPTIMIZING THE PRIVILEGE OF ACEH (Constitutional Perspective)
}

\author{
Cakra Arbas \\ Post Graduate Lecturer of Law Science, \\ University of Muhammadiyah Sumatera Utara (UMSU) \\ c4k124@rocketmail.com
}

\section{ARTICLE INFORMATION}

Article history:

Received June 13, 2017

Revised Nov 08, 2017

Accepted Dec 11, 2017

JEL Classifications

K42; K49

\section{Key Words:}

Aceh;

Privileges;

Corruption.

\section{DOI:}

10.21532/apfj.001.17.02.02.06

\begin{abstract}
Eradication of corruption is one way to accelerate national developmentaimed atrealizingjustice, prosperity, andorder for the Indonesian people as a whole based on Pancasila and 1945 Constitution of the Republic of Indonesia. Aceh has been positioned as a special regional government unit, which is a crystallization of the values contained in the local wisdom of the Acehnese people, such as upholding the principle of divinity in all social activities, including in the scope of local government that always adhere to romantic customs.
\end{abstract}

The Essence of the foundation for preventing corruption, especially in Aceh, has been attempted by establishing organic regulations, such as Qanun (from Acehnese language means legislation). Substantially, however, the organic regulations are sometimes not directly addressed to the term of corruption. Therefore, it is necessary to formulate regulation as an effort to accommodate the eradication of criminal acts of corruption. On the same occasion, the synergy of customary institutions as the lowest level of local government unit becomes a necessity, especially Imeum Mukim (from Acehnese language means head of customary government). Imeum Mukim can serve as a locomotive to prevent corruption by strengthening his integrity and competence.

The research method used is normative legal research. The type of data used is secondary data, consisting of primary legal material (various forms of legislation), secondary legal materials (data collection of scientific work of scholars and the results of the research relating to the privilege of Aceh Province), and tertiary legal materials (materials providing information on primary legal materials and 
secondary legal materials, such as dictionaries and encyclopedias). Once the data are collected and considered to be complete enough, the next step is to manage and analyze the data. Data analysis is conducted using qualitative data analysis technique.

\section{A. Introduction}

The constitutional journey of the Republic of Indonesia has experienced ups and downs of leadership, one of which when the turmoil of reform took place demanding for the realization of new state leaders who are free from various alleged corrupt practices. Eventually, the massive voice of the people could undermine the dominance of power wall that was considered to have deviated from the basic principles of government, or commonly known as the principle of good and clean government.

Corruption in Indonesia occurs systematically and extensively. It not only harms the state's finances but also violates the social and economic rights of society at large. The eradication of corruption needs to be done in an extraordinary way. Post-reformation, as an effort to prevent and eradicate corruption in Indonesia, the government enacted Law No. 30 Year 2002 on the Corruption Eradication Commission (better known in Indonesia as KPK) which subsequently became the spearhead of anti-corruption until today.

National development is aimed at realizing justice, prosperity, and order for the Indonesian people as a whole based on Pancasila and the 1945 Constitution. However, corruption has been detrimental to the state's finance, economy and national development. Therefore, the eradication of corruption is an urgent agenda that must be conducted and improved professionally, intensively, and sustainably.

On the same occasion, Indonesia, through laws and regulations, acknowledges and respects the privilege and specificity of regional government units. This is expressly stated in Article 18B of the 1945 Constitution of the Republic of Indonesia. ${ }^{1}$ Aceh has been positioned as a special regional government unit due to the typical character of the history of the struggle of the Acehnese people who have high resilience and fighting power.

One of the privileges and specificities embedded in Aceh Province is the result of a living and growing abstraction value in Acehnese society. The crystallization of the values contained in the local wisdom of the people of Aceh includes upholding the principle of divinity in all social activities, without exception in the scope of the implementation of local government. In addition to the divine principle, the people of Aceh also cling to the romantic customs, in which today it is described through the structure of customary institutions that are accommodated in Law no. 11 Year 2006 on the Government of Aceh.

Based on the local wisdom of the Acehnese people, it can be observed that corruption is not a cult act. Even when reflecting on the divinity principles, corruption is a disgraceful act. If the existence of customary institutions can be maximized, it will be possible to realize the government, particularly in Aceh, which is free from alleged corruption practices. Therefore, the local wisdom of the Acehnese people can be made as a paradigm for the implementation of national governance, especially by strengthening the divine principle and optimizing the role of customary institutions as the front guard of society in preventing corruption.

\section{B. Research Method}

The research method used is normative legal research. The type of data used is secondary data, consisting of primary legal material (various forms of legislation),

\footnotetext{
1 Article 18B (1) of the 1945 Constitution of the Republic of Indonesia declares that "the state acknowledges and respects the privilege and specificity of Regional Government regulated by Law".
} 
secondary legal materials (data collection of scientific work of scholars and research results relating to the privilege of Aceh Province), and tertiary legal materials (materials providing information on primary legal materials and secondary legal materials, such as dictionaries and encyclopedias). Once the data are collected and considered to be complete enough, the next step is to manage and analyze the data. Data analysis is conducted using qualitative data analysis technique.

\section{Discussion}

\section{The Dynamics of Legislation on Aceh}

Legislation on Aceh has been experiencing dynamics in accordance with the applicable constitution in Indonesia, especially regarding substantive issues on the authority of Aceh. The dynamics of legislation relating to the privilege of Aceh can be reviewed as follows:

a. The decree of the Prime Minister of the Republic of Indonesia No. $1 /$ Missi / 1959 on the Determination of Aceh Province as the Special Region of Aceh.

That, under the leadership of Deputy Prime Minister I (Mr. Hardi), then commonly known as "Missi Hardi", on May 26, 1959 resulted in a Decree of the Prime Minister of the Republic of Indonesia No. 1 / Missi / 1959 on the Determination of Aceh province as the Special Region of Aceh, with the broadest autonomy, especially in the fields of: ${ }^{2}$ Religion, Custom, Education.

\footnotetext{
2 The Decree of the Prime Minister of the Republic of Indonesia No. 1 / Missi / 1959 on the Determination of the First Level Region of Aceh as the Special Region of Aceh, at Point "a". See also in Hardi, Api Nasionalisme Cuplikan Pengalaman, (Jakarta: Gunung Agung, 1983), p. 137-139. See also in the Ministry of Education and Culture, Sejarah Daerah Provinsi Daerah Istimewa Aceh, (Jakarta: Depdikbud, 1977), p. 189. See also in M. Nur El Ibrahimy, Tgk M. Daud Beure'euh, Peranannya Dalam Pergolakan di Aceh , (Jakarta: Gunung Agung, 1986), p. 175.
}

The birth of "Missi Hardi" was an aspiration that has been stated by the people of Aceh, especially related to the religious field, as presented by Tgk M. Daud Beureueh to Soekarno (as President of the Republic of Indonesia), during his visit to Aceh. After the birth of "Missi Hardi", the Government of the Republic of Indonesia, in fact, did not immediately revise the law and regulation on Aceh. In addition, the Government also did not enact a new law accommodating the "Missi Hardi", thus resulting in latent vertical conflict in Aceh.

b. Law no. 44 Year 1999 on the Implementation of Special Region of Aceh Province

In the context of governance in Aceh, on October 4, 1999 was born Law no. 44 of 1999 on the Implementation of Special Region of Aceh Province. The birth of this law was basically to accommodate the things that had been approved on "Missi Hardi" in the fields of religion, custom, and education. During this period the Government of the Republic of Indonesia began to realize to immediately stop the ongoing vertical conflict in Aceh, that is, by accommodating the aspirations developed widely in the people of Aceh. Therefore, the law was expected to be accepted by all layers of the Acehnese people.

Law no. 44 Year 1999, on the Implementation of Special Region of Aceh Province, emphasizes more about the privilege of $\mathrm{Aceh}^{3}$ The privilege of Aceh, based on this law,

\footnotetext{
Privilege is the recognition of the Indonesian nation given to a region because of the struggle and the intrinsic values of the community kept up from generation to generation as a spiritual, moral, and humanitarian base. Article 3 (1) of Law no. 44 Year 1999 on the Implementation of Special Region of Aceh Province.
} 
includes ${ }^{4}$ : first, the implementation of religious life; second, the implementation of customary life; third, the implementation of education, and fourth, the role of Islamic religious leaders in determining regional policy.

It should be noted that the special authority of Aceh, in principle, has been agreed upon by the Government of the Republic of Indonesia through "Missi Hardi", but it could only be realized about 40 years later through Law no. 44 Year 1999 on the Implementation of Special Region of Aceh Province. This could actually determine the development of politics of law in Aceh, and would have different results if it had been be realized early. On the other hand, the metamorphosis of legislation on the implementation of local government in Aceh was inseparable from the development of local government in the national context, which was the output of the political turmoil in the birth of the reform demands that took place in the 1998 .

c. Law No. 11 Year 2006 on Aceh Government

Various efforts have been made by the Government of the Republic of Indonesia to minimize continuous vertical conflicts, such as through military approach, legal approach, regulatory approach, and negotiations between the parties related in the reform era. Finally, on August 15, 2005, both parties agreed with the birth of a Memorandum of Understanding (MoU) of Helsinki between the Government of the Republic of Indonesia and the Free Aceh Movement (better

\footnotetext{
4 Article 3 (2) of Law no. 44 Year 1999 on the Implementation of Special Region of Aceh Province
}

known in Indoensa as GAM). The signing of the Helsinki MoU, in its development, has become a new flash of the history of Aceh Province's journey as well as the people's lives towards a peaceful, just, prosperous, prosperous and dignified state. In this case, the parties were determined to create better conditions so that the government of Aceh could be realized through a democratic and fair process within the framework of the Unitary State of the Republic of Indonesia (NKRI).

Under the Helsinki MoU, the Government of the Republic of Indonesia and the Free Aceh Movement (GAM) agreed on matters, such as "The new Law on the Implementation of Aceh government will be enacted and shall come into force as soon as possible and not later than March 31, 2006"..5

The mandate of the Helsinki MoU to bring about a new law on Aceh was responded by the Government of the Republic of Indonesia with the birth of Law no. 11 Year 2006. The dynamic aspirations of the Acehnese people not only in customary, cultural, social and political life adopting the privileges of Aceh, but also in providing assurance of legal certainty in all matters because the religious basic life of the Acehnese people has shaped good attitudes, high morale, and strong Islamic culture. $^{6}$

Law no. 11 Year 2006 on the Aceh Government, in principle, regulates the special authority of the

\footnotetext{
Point 1.1.1 MoU between the Government of the Republic of Indonesia and the Free Aceh Movement (GAM). The mandate should have been realized not later than March 31, 2006, but the mandate can only be realized on August 1, 2006, with the issuance of Law no. 11 Year 2006 on Aceh Government.

6 Law no. 11 Year 2006 on Aceh Government, on General Explanation.
} 
Government of Aceh. The regional authority in implementing special autonomy is to hold the authority that is still under the authority of the Government of the Republic of Indonesia. ${ }^{7}$ Law no. 11 Year 2006 on Aceh Government has become the essence in organizing the new Aceh Government. As stated by Ahmad Farhan Hamid ${ }^{8}$ that Law no. 11 Year 2006 on Aceh Government is a golden bridge to new Aceh, which is not only peaceful, but also just and prosperous. The next is the sincerity and commitment of the parties to implement it.

\section{Optimizing Local Wisdom as the Privilege of Aceh}

Maintaining local wisdom is in line with the adage "think globally, act locally", meaning that all actions, especially in the implementation of government should be based on local wisdom that has lived and developed in the community. Without exception, the initiation to maintain local wisdom should also be implemented by one of the autonomous regions mandated by

\footnotetext{
Husni Jalil in M. Solly Lubis, Paradigma Kebijakan Hukum Pasca Reformasi, (Jakarta: PT Sofmedia, 2010), p. 120.

The special authority, in Law No. 11 Year 2006 on Aceh Government, in accordance with Article 7, states that: (1) The Government of Aceh and the Government of Regency / City are authorized to regulate and administer the government affairs in all public sectors except the government affairs that are under the authority of the Government. (2) The government authorities as referred to in paragraph (1) shall cover the national affairs, foreign policy, defense, security, justice, monetary and national fiscal, and certain religious affairs. (3) In implementing the authority of the Government under its own authority as referred to in paragraph (2), the Government may: First, Implement itself. Second, Submit some of the Government's authority to the Government of Aceh and the Government of Regency / City. Third, Delegate some of them to the Governor as the Government representative and / or the Government agencies. Fourth, assign some of the affairs to the Government of Aceh and Government of regency / City and gampong based on the task of assistance.

8 Ahmad Farhan Hamid, Jalan Damai Nanggroe Endatu Catatan Seorang Wakil Rakyat Aceh, (Jakarta: Suara Bebas, 2006), hal. 476.
}

the privilege, that is, Aceh Province.

This is at least reflected through the hadih maja of Aceh (a past adage) in Aceh language "Adat bak Poteumeurhom, HukumbakSyiahKuala, Qanun bak Putroe Phang, Reusam bak Laksamana". Based on the phrases, it should be understood that the reflection of the legitimacy of local wisdom, including the customs as well as Islamic Shari'a essentially has become part of the life of the people of Aceh. Today the organization of community life in Aceh has accommodated the past adage of various results of the abstraction of the value of the Acehnese community, which is further realized through Qanun, whether it is the Aceh Qanun on the development of indigenous life and customs, and Qanun Aceh on Islamic Shari'a, and Qanun Aceh on Jinayat (from Aceh language means the study of Islamic jurisprudence on criminality)

a. Optimizing Islamic Shari'ah

The legitimacy of the implementation of Islamic Shari'ah in Aceh is mandated by Law No. 11 of 2006 on the Government of Aceh, especially Article 125 (1) "Islamic Shari'ah implemented in Aceh encompassing aqidah, syar'iyah and morals". Article 126 (1) "Every follower of Islam in Aceh is obliged to obey and practice Islamic Shari'ah." And Article 126 (2) "Everyone residing in Aceh shall respect the implementation of Islamic Shari'ah."

Based on the mandate of several articles, there are currently organic regulations that are competent to describe the implementation of Islamic Shari'ah in Aceh, that is,: first, the Aceh Qanun on Jinayat 
$\mathrm{Law}^{9}$, second, the Aceh Qanun on Islamic Shari' ah ${ }^{10}$.

Interestingly, when the various juridical foundationsinimplementing the Islamic Shari'ah of Islam are associated with the principles of good and clean government governance, one of which is the principle of not committing corruption, firmly and clearly there will be no arrangement and prohibition on corruption, because the arrangement of Islamic Shari'ah in Aceh only includes aqidah, syar'iyah and morals. ${ }^{11}$

On the same occasion, it should be understood that based on historical records from the seventeenth to the nineteenth centuries, Aceh had reached the pinnacle of its glory, especially in the application of Islamic Shari'ah. One indication of the application of Islamic Shari'ah can be examined from the view of Dampier as follows:

"... on the first act of theft, a thief is punished by cutting off the right wrist, on the second by cutting off the left hand, and sometimes also by cutting off one or both legs. Although it is rare, a thief is also punished by cutting off both hands and feet. If after losing one or both arms and legs, the perpetrator still commits a similar crime, for example by stealing using the rest of the body, the perpetrator is thrown into Weh Island for life. This type of punishment is given especially

\footnotetext{
9 Qanun Aceh No 6 Tahun 2014 tentang Hukum Jinayat.

10 Qanun Aceh No 8 Tahun 2014 tentang Pokok-Pokok Syariat Islam.

11 Lihat dalam Pasal 125 Undang-Undang No. 11 Tahun 2006 tentang Pemerintahan Aceh, jo Pasal 3 Qanun Aceh No. 6 Tahun 2014 tentang Hukum Jinayat, serta jo Pasal 2 Qanun Aceh No. 8 Tahun 2014 tentang Pokok-Pokok Syariat Islam.
}

in the case of large thefts. However, for petty small theft of the perpetrators for the first time will be whipped, while for the repeated small theft is considered a great theft, and the death penalty has never been imposed on the thief... "

In the context of analogy of corruption as one element of theft, then in Islamic law is known two types of theft; first, small theft (alsariqah al-sughra); second, the big theft (al-sariqah al-kubra) just like a robbery in the street. For this theft, the hadd punishment is given, based on the fundamental reason that a thief has violated God's right. And then the hand-cut penalty is imposed, while the violation of the right of the victim is done by replacing it $^{12}$.

As for the penalty of exile (as told by Dampier with exile to Weh Island), it should be understood as ta'zir and permissible in Islamic law. It is addressed to acute perpetrators who can no longer be healed through a hadd-like penalty. Therefore, this punishment clearly shows a way to prevent the perpetrator from repeating his actions and also a lesson for others not to commit a crime $^{13}$.

\section{b. Optimizing Customary Institution}

One of the efforts to minimize the corruption in Aceh is usually derived from legislation, that is, the establishment of "Aceh Qanun on the Development of Indigenous Life and Customs". ${ }^{14}$ In essence, Qanun is defined as the rules of deeds and

\footnotetext{
12 Amirul Hadi, Op. Cit., hal. 182.

13 Ibid., hal. 186.

14 Qanun No. 9 Year 2008 on the Development of Indigenous Life and Customs.
} 
habits that have been applied in the community as guidance in the interaction of life in Aceh. While customary law is a set of unwritten provisions that lives and thrives in Acehnese society and has sanctions.

On the same occasion, Amirul Hadi ${ }^{15}$ explained that "adat" is a word adopted from Arabic, derived from the word 'adah', having a sense of habit or practice. While theoretically 'adah' is often known by the term ' $u r f$ ' and has never been an official source for Islamic law. But in its implementation, it is often integrated in one of Islamic law references, ' $a d a h$ ' is sometimes used when the main sources of Islamic law (the Qur'an, Hadits, Ijma', and Qiyas) do not explain what is meant. However, it does not mean that laws derived from 'adah' are contrary to Islamic law.

In the context of the rule of law, the current administration in Aceh government has implemented several customary institutions, among others as mandated in the Aceh Qanun on the Development of Indigenous Life and Customs. The various institutions are $^{16}$ : first, the Aceh Traditional Assembly; second, Imeum Mukim; third, Imeum Chi;. fourth, Keuchik; fifth, Tuha Peut; sixth, Tuha Lapan; seventh, Imeum Meunasah; eighth, Keujruen Blang; ninth, Panglima Laot; tenth, Pawang Glee / Uteun; eleventh, Petua Seunebok; twelfth, Haria Peukan; thirteenth, Syahbanda.

All customary institutions accommodated in the government of Aceh have certain competencies

15 Amirul Hadi, Op. Cit., hal. 173.

16 Article 2 (2) Qanun No. 9 Year 2008 on Development of Indigenous Life and Customs. and different tasks as well as functions. However, in the context of a corruption eradication strategy, at least it is closely related to the consistency of customary institutions such as "Imeum Mukim", because Imeum Mukim essentially carries a mandate for duties ${ }^{17}$ : first, performing community coaching; second, carrying out the customary activities; third, resolving the dispute; fourth, helping improve the implementation of Islamic Shari'ah; fifth, assisting the government administration; sixth, assisting the implementation of development.

Referring to the authority possessed by the "Imeum Mukim", M. Ja'far Puteh ${ }^{18}$ affirms that Imeum Mukim is responsible for overseeing the daily life of his territory and has the authority to crack down on people who violate the customs in his territory. Therefore, Imeum Mukim is positioned as a law enforcer to various indications of corrupt practices. Given that by strengthening the capacity of the Imeum Mukim figure, the Imeum Mukim should be a role model for the people of his region, thus Imeum Mukim indirectly has an active role in minimizing various corrupt habits.

\section{Conclusion}

Based on the description of the efforts to minimize corruption through the optimization of the privilege of Aceh Province (the constitutional perspective), at least there is a linkage that in the course of the constitution of the Republic of Indonesia, it is not a taboo to abstract the various local wisdom that live

18 M. Ja'far Puteh, Sistem Sosial Budaya dan Adat Masyarakat Aceh, (Banda Aceh: Grafindo Litera Media, 2012), page. 60 .
} 
and develop in each autonomous region to be implemented without exceptionally by the Aceh government despite the ups and downs in the juridical legitimacy of the value derivation embodied through legislation on Aceh.

In essence, the foundation for preventing corruption, especially in Aceh, has been pursued by establishing organic regulations such as Qanun, but substantially the various organic regulations sometimes have not directly addressed to the term of corruption. This means that regulation reform is needed as an effort to accommodate corruption. On the same occasion, the synergy of customary institution as an enforcer in the lowest local government unit is necessary. Especially, Imeum Mukim can be used as a locomotive to prevent corruption by strengthening his integrity and competence.

\section{F. References}

- Departemen Pendidikan dan Kebudayaan, Sejarah Daerah Provinsi Daerah Istimewa Aceh, Depdikbud, Jakarta, 1977.

- El Ibrahimy, M. Nur, Tgk M. Daud Beure'euh Peranannya Dalam Pergolakan di Aceh, Gunung Agung, Jakarta, 1986.

- Hadi, Amirul, Aceh Sejarah, Budaya, dan Tradisi, Yayasan Pustaka Obor Indonesia, Jakarta, 2010.

- Hamid, Ahmad Farhan, Jalan Damai Nanggroe Endatu Catatan Seorang Wakil Rakyat Aceh, Suara Bebas, Jakarta, 2006.

- Hardi, Api Nasionalisme Cuplikan Pengalaman, Gunung Agung, Jakarta, 1983.

- Lubis, M. Solly, Paradigma Kebijakan Hukum Pasca Reformasi, PT. Sofmedia, Jakarta, 2010.

- Nota Kesepahaman Antara Pemerintah Republik Indonesia dan Gerakan Aceh Merdeka.
- $\quad$ Puteh, M. Ja'far, Sistem Sosial Budaya dan Adat Masyarakat Aceh, Grafindo Litera Media, Banda Aceh, 2012.

- Undang-Undang Dasar Negara Republik Indonesia Tahun 1945

- Keputusan Perdana Menteri Republik Indonesia No. 1/Missi/1959 tentang Penetapan Daerah Swatantra Tingkat I Aceh Sebagai Daerah Istimewa Aceh.

- Undang-Undang No. 44 Tahun 1999 tentang Penyelenggaraan Keistimewaan Provinsi Daerah Istimewa Aceh.

- Undang-Undang No. 11 Tahun 2006 tentang Pemerintahan Aceh.

- Qanun Aceh No 6 Tahun 2014 tentang Hukum Jinayat.

- Qanun Aceh No 8 Tahun 2014 tentang Pokok-Pokok Syariat Islam.

- Qanun No. 9 Tahun 2008 Qanun Aceh tentang Pembinaan Kehidupan Adat dan Adat Istiadat. 